University of Nebraska - Lincoln

DigitalCommons@University of Nebraska - Lincoln

$12-2017$

\title{
Understanding and Finding Solutions to the Problem of Sedimentation in the National Wildlife Refuge System
}

Max Post van der Burg

Karen E. Jenni

Timothy L. Nieman

Josh D. Eash

Gregory A. Knutsen

Follow this and additional works at: https://digitalcommons.unl.edu/usgsnpwrc

Part of the Animal Sciences Commons, Behavior and Ethology Commons, Biodiversity Commons, Environmental Policy Commons, Recreation, Parks and Tourism Administration Commons, and the Terrestrial and Aquatic Ecology Commons

This Article is brought to you for free and open access by the US Geological Survey at DigitalCommons@University of Nebraska - Lincoln. It has been accepted for inclusion in USGS Northern Prairie Wildlife Research Center by an authorized administrator of DigitalCommons@University of Nebraska - Lincoln. 
Issues and Perspectives

\title{
Understanding and Finding Solutions to the Problem of Sedimentation in the National Wildlife Refuge System
}

\author{
Max Post van der Burg,* Karen E. Jenni, Timothy L. Nieman, Josh D. Eash, Gregory A. Knutsen \\ M. Post van der Burg \\ U.S. Geological Survey, Northern Prairie Wildlife Research Center, 8711 37th Street SE, Jamestown, North Dakota 58401 \\ K.E. Jenni \\ U.S. Geological Survey, Science and Decisions Center, W. 6th Avenue Kipling Street 939, Lakewood, Colorado 80225 \\ T.L. Nieman \\ Decision Applications, Inc., 1390 Grove Court, Saint Helena, California 94574
}

J.D. Eash

U.S. Fish and Wildlife Service, 5600 American Boulevard W., Bloomington, Minnesota 55437

\section{G.A. Knutsen}

U.S. Fish and Wildlife Service, Agassiz NWR, 22996 290th Street NE, Middle River, Minnesota 56737

\begin{abstract}
The National Wildlife Refuge System (Refuge System) is a collection of public lands maintained by the U.S. Fish and Wildlife Service for migratory birds and other wildlife. Wetlands on individual National Wildlife Refuges (Refuges) may be at risk of increased sedimentation because of land use and water management practices. Increased sedimentation can reduce wetland habitat quality by altering hydrologic function, degrading water quality, and inhibiting growth of vegetation and invertebrates. On Refuges negatively affected by increased sedimentation, managers have to address complex questions about how to best remediate and mitigate the negative effects. The best way to account for these complexities is often not clear. On other Refuges, managers may not know whether sedimentation is a problem. Decision makers in the Refuge System may need to allocate resources to studying which Refuges could be at risk. Such analyses would help them understand where to direct support for managing increased sedimentation. In this paper, we summarize a case study demonstrating the use of decision-analytic tools in the development of a sedimentation management plan for Agassiz National Wildlife Refuge, Minnesota. Using what we learned from that process, we surveyed other Refuges in U.S. Fish and Wildlife Service Region 3 (an area encompassing the states of Illinois, Indiana, lowa, Ohio, Michigan, Minnesota, Missouri, and Wisconsin) and Region 6 (an area encompassing the states of Colorado, Kansas, Montana, Nebraska, North Dakota, South Dakota, Utah, and Wyoming) about whether they experience sediment-related impacts to management. Our results show that cases of management being negatively affected by increased sedimentation are not isolated. We suggest that the Refuge System conduct a comprehensive and systematic assessment of increased sedimentation among Refuges to understand the importance of sedimentation in context with other management problems that Refuges face. The results of such an assessment could guide how the Refuge System allocates resources to studying and managing widespread stressors.
\end{abstract}

Keywords: National Wildlife Refuge System; sedimentation; structured decision making; wetlands

Received: January 15, 2015; Accepted: June 9, 2017; Published Online Early: July 2017; Published: December 2017

Citation: Post van der Burg M, Jenni KE, Nieman TL, Eash JD, Knutsen GA. 2017. Understanding and finding solutions to the problem of sedimentation in the National Wildlife Refuge System. Journal of Fish and Wildlife Management 8(2):647660; e1944-687X. doi:10.3996/012016-JFWM-004

Copyright: All material appearing in the Journal of Fish and Wildlife Management is in the public domain and may be reproduced or copied without permission unless specifically noted with the copyright symbol $\odot$. Citation of the source, as given above, is requested.

The findings and conclusions in this article are those of the author(s) and do not necessarily represent the views of the U.S. Fish and Wildlife Service. 
*Corresponding author: maxpostvanderburg@usgs.gov

\section{Introduction}

The National Wildlife Refuge System (Refuge System) is a collection of public lands maintained by the U.S. Fish and Wildlife Service for migratory birds and other wildlife. The U.S. Fish and Wildlife Service acquired many of these lands following the drought of the 1930s. National Wildlife Refuges (Refuges) that contain wetlands drained for agricultural production were restored through a variety of infrastructure improvements (e.g., dikes, water control structures). These wetlands were managed as impoundments in an effort to create a network of secure waterbird habitats. The combination of altered landscapes (i.e., grasslands replaced with row crop agriculture) and altered upstream hydrologic systems (i.e., intensive ditching and wetland drainage) can turn restored wetlands into sediment traps (e.g., Kreiling et al. 2013). Wetland impoundments that experience elevated sedimentation rates are likely to be degraded, and may not effectively support wildlife populations.

Sedimentation in wetlands is a natural process; however, the effects of accelerated sediment deposition can be negative across a range of wetland systems (Barendregt and Swarth 2013; Burris and Skagen 2013). Increased sedimentation negatively affects plant community composition (Gleason et al. 2003; Tsai et al. 2012; Beas et al. 2013), as well as invertebrate and vertebrate populations (Gleason et al. 2003; Venne et al. 2012). There have been systematic studies of sedimentation and water quality in Refuge wetlands. Some of these studies found elevated rates of sedimentation (e.g., Heimann and Richards 2003; Fitzpatrick et al. 2007; Schottler and Engstrom 2011; Nustad and Galloway 2012), while others did not (e.g., Tangen et al. 2014).

Sedimentation has the potential to be a widespread phenomenon among Refuges given the land use changes of the past $80 \mathrm{y}$. On Refuges negatively affected by increased sedimentation, managers have to address complex questions about how to best remediate and mitigate the negative effects. The best way to account for these complexities often is not clear. On other Refuges, managers may not know whether sedimentation is a problem. Decision makers in the Refuge System may need to allocate resources to studying which Refuges could be at risk. Such analyses would help them understand where to direct support for managing increased sedimentation. In this paper, we summarize a case study demonstrating how we used decision-analytic tools in the development of a sedimentation management plan for Agassiz National Wildlife Refuge (Agassiz NWR), Minnesota. Using what we learned from that process, we surveyed other Refuges about whether they experience sediment-related impacts to management. We use the results of this survey to draw some general conclusions about what increased sedimentation may mean across Refuges and whether further study of sedimentation in the Refuge System is warranted.

\section{Case Study: Mitigating and Remediating Sedimentation at Agassiz National Wildlife Refuge}

Most studies of sedimentation in the Refuge System quantify or describe sedimentation on an individual Refuge. However, these studies do not make specific suggestions about how to mitigate or remediate any negative impacts. Developing mitigation or remediation strategies is a complex problem that involves the unique circumstances of each Refuge, as well as the objectives of surrounding landowners and other state and federal managers. Below we summarize a case study that demonstrates the use of decision-analytic tools to explore potential solutions to increased sedimentation at a single Refuge in the context of these complexities.

Agassiz NWR is a 24,890 -ha complex of wetlands and uplands located within the Thief River Watershed in northwestern Minnesota, which includes 21 managed impoundments that are maintained and regulated through a system of dikes and water control structures. These structures capture and regulate water from tributaries that flow into and through Agassiz NWR, which is surrounded by an agricultural landscape that has been drained by $>1,930 \mathrm{~km}$ of county, state, and judicial ditches (Hanson 2010). Agricultural land use has degraded stream quality in the Thief River Watershed to such an extent that the Minnesota Pollution Control Agency and the Environmental Protection Agency designated these streams as impaired. Streams play a role in providing water to the Agassiz NWR; therefore, researchers have conducted multiple investigations quantifying sediments and contaminants flowing into and out of Agassiz NWR. These studies highlight the consequences of increased sedimentation on Agassiz Pool (Figure 1), which is the largest impoundment at 4,047 ha. Inorganic sediments enter Agassiz Pool from two primary sources: the Thief River flowing through the northwest corner of Agassiz NWR, and from Ditch 11, which flows from east to west through Agassiz Pool. Managers have some control over water levels in Agassiz Pool via radial gates (primary outlet structure) on the west end of Ditch 11.

Agassiz Pool captures approximately $\geq 57 \%$ of all the sediment that flows through it (Hanson 2010; Houston Engineering, Inc. 2011). Stated another way, approximately 1,084,000 metric tons of inorganic sediment accumulated in Agassiz Pool and Ditch 11 during the period spanning 1940-2008 (Schottler and Engstrom 2011). These studies indicate that erosion from agricultural fields is one of the primary sources of increased sediment loads entering Agassiz NWR. Increased sedi- 


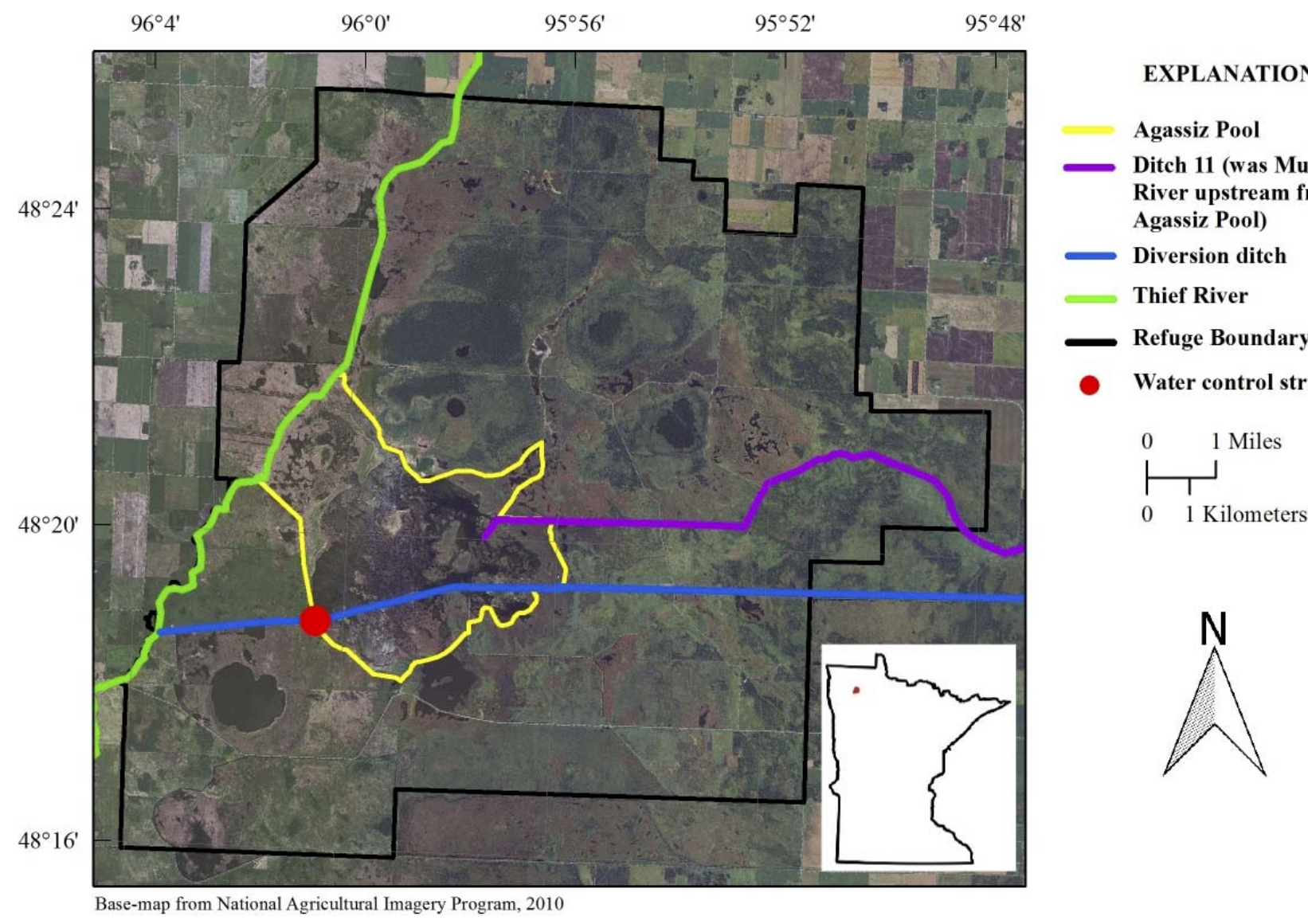

Figure 1. Map of Agassiz National Wildlife Refuge located in northwestern Minnesota. This map shows the locations of Agassiz Pool and the various inlets for water within and around the Refuge at the time of a structured decision making workshop held in 2012. The inset (lower right-hand corner) shows the location of the Refuge (in red) in the state of Minnesota.

mentation in Agassiz Pool limits what staff can do to manage waterbird habitat. Water levels frequently exceed management targets and threaten overwater nesting birds. Periodic drawdowns of Agassiz Pool are ineffective because sediment in Ditch 11 restricts water from leaving the Pool. Increased sedimentation also correlates with the loss of various wetland plant species and an expansion of hybrid cattail (Typha $\times$ glauca). Thus, staff believe the quality of Agassiz Pool as waterbird habitat is declining.

\section{Decision framing}

We used a structured decision making (Gregory et al. 2012) approach to propose and assess some potential solutions to this management problem. Agassiz NWR staff wanted to explore options that included efforts to reduce sediment inputs while also taking steps to remove accumulated sediment and reduce cattail abundance. They recognized that sediment reduction strategies required involvement from upstream agricultural producers and downstream county and municipal officials. We included these perspectives by inviting staff from Agassiz NWR, local producers, municipal officials, and technical experts to participate in a workshop. Our goal with the workshop was to help Agassiz NWR staff develop management objectives and potential strategies.

\section{Objectives}

We elicited two sets of fundamental management objectives. The first set was from the perspective Agassiz NWR staff and the second set was from the perspective of local producers and county and municipal officials. The first set of objectives focused on increasing the habitat quality of Agassiz Pool and decreasing management costs. The second set included minimizing flooding risk and municipal water treatment costs; as well as maintaining flood water and sediment storage capacity. Capturing these other values is important because they may conflict with the objectives of Agassiz NWR staff. Failure to account for this conflict could lead to the development of solutions that are technically or politically infeasible.

Workshop participants regarded some of these objectives as difficult to estimate. Through subsequent discussions, we identified a second tier of means objectives that our technical experts considered easier to estimate, but that are connected to the first tier of objectives. These objectives are also more closely tied to management interventions. We organized these objec- 
tives into an objectives network (Keeney 1992) to show how they are related (Figure 2).

\section{Alternative actions and strategies}

We elicited a list of actions that affected the means objectives discussed above. We organized these actions (sensu Clemen and Reilly 2001) into a strategy generation table (Table 1). Using Table 1, we then elicited combinations of alternative actions from each action type and organized them into comprehensive strategies (Table 2). Options in Table 2 do not include all of the possible actions in the strategy generation table, but rather those that Agassiz NWR staff felt are feasible. Each strategy contains elements to address 1) sediment loading in supply water, 2) water flow into Agassiz Pool, and 3) accumulated sediment within the Pool. Below are descriptions of each strategy.

Strategy 1: Management changes and upstream focus. Agassiz NWR staff will promote sediment-reducing agricultural practices and conservation programs to upstream landowners. Staff will also conduct more frequent drawdowns and more active management of cattails to limit habitat degradation.

Strategy 2: Bypass focus. Staff will utilize regulation of incoming flows by installing bypasses on the Thief River, Diversion Ditch, and Ditch 11.

Strategy 3: Emphasize drawdowns. Staff will use repeated drawdowns to remove existing sediment, requiring mechanical removal of sediment from Ditch 11. The Thief River bypass will allow better control of sediment entering from the Thief River.

Strategy 4: Engineered strategy. Staff will combine Strategy 3 with active controls in Ditch 11 and repeated drawdowns over $10 \mathrm{y}$.

Strategy 5: Bypass and drawdown combination. Staff will combine Strategies 2 and 3.

Strategy 6: Drawdown and engineered combination. Staff will combine Strategies 3 and 4 .

\section{Consequences assessment}

We assessed the consequences of all six strategies in terms of their ability to affect management objectives (Table 3). We relied on Agassiz NWR staff and the knowledge of technical experts to make the assessment. Based on the results, Agassiz NWR staff decided to move forward with a more detailed qualitative assessment of three strategies (Table S1). We document the general findings of the assessment below.

Strategy 1. Staff expected that this strategy would lead to little improvement in management objectives over the next $10 \mathrm{y}$. They expected upstream and downstream objectives were also unlikely to improve, but that the short-term cost of this strategy would be comparatively low. They expected that long-term management costs would increase because accumulated sediment would eventually need to be excavated out of Agassiz Pool.

Strategy 5. Staff expected their ability to meet management objectives over the next $10 \mathrm{y}$ would increase. They also expected upstream and downstream objectives to improve modestly in the near term, with more appreciable increases in performance in the long term as their ability to dry Agassiz Pool increases. They estimated that this strategy would be much more expensive than options 1 or 6 , primarily because of the Diversion Ditch bypass. Sediment increases associated with drawdowns may also increase water treatment costs downstream, but they thought this would decrease over time as stored sediment levels in the Pool decreased.

Strategy 6. Staff expected the performance of this strategy to be similar to Strategy 5. This strategy provided fewer options for routing water flows, so they expected this strategy would provide slightly lower flood management capability than Strategy 5. They also expected this strategy may increase costs to downstream municipal water-treatment facilities. Staff expected that the primary benefit of Strategy 6 over Strategy 5 was mainly financial. In the short term, they estimated that management costs would be approximately US\$3 million less than Strategy 5.

\section{Selection of preferred alternative and potential information needs}

As Keeney (2004) points out, many decision problems can be resolved by systematic thinking consistent with decision analysis, rather than going through an entire quantitative decision analysis. Agassiz NWR staff felt confident in choosing to pursue Strategy 6 based on their qualitative analysis. They expected this strategy to provide similar benefits to Strategy 5 with anticipated lower costs, while also allowing flexibility in implementation. One of the values of this exercise was the open discussion between Agassiz NWR staff and other decision makers who may be affected by sediment management decisions. Discussions between staff and downstream municipal officials about impacts to water quality increased transparency and comfort with plans to implement the preferred strategy.

The analysis presented here also raised questions about the effectiveness of the preferred strategy. Staff expressed uncertainty about how actions should be sequenced, how much sediment can be removed, and how much sediment removal is required to improve management objectives. They were also uncertain about the long-term effects of sediment releases from Agassiz Pool on downstream infrastructure, such as water treatment plants, and the effectiveness of outreach programs in reducing upstream sediment from entering the Pool. Continued monitoring will be a critical element of assessing whether implementation is successful. To be useful, monitoring targets must provide information on the management objectives and one or more of the uncertainties that remain about the effectiveness of the strategy. 


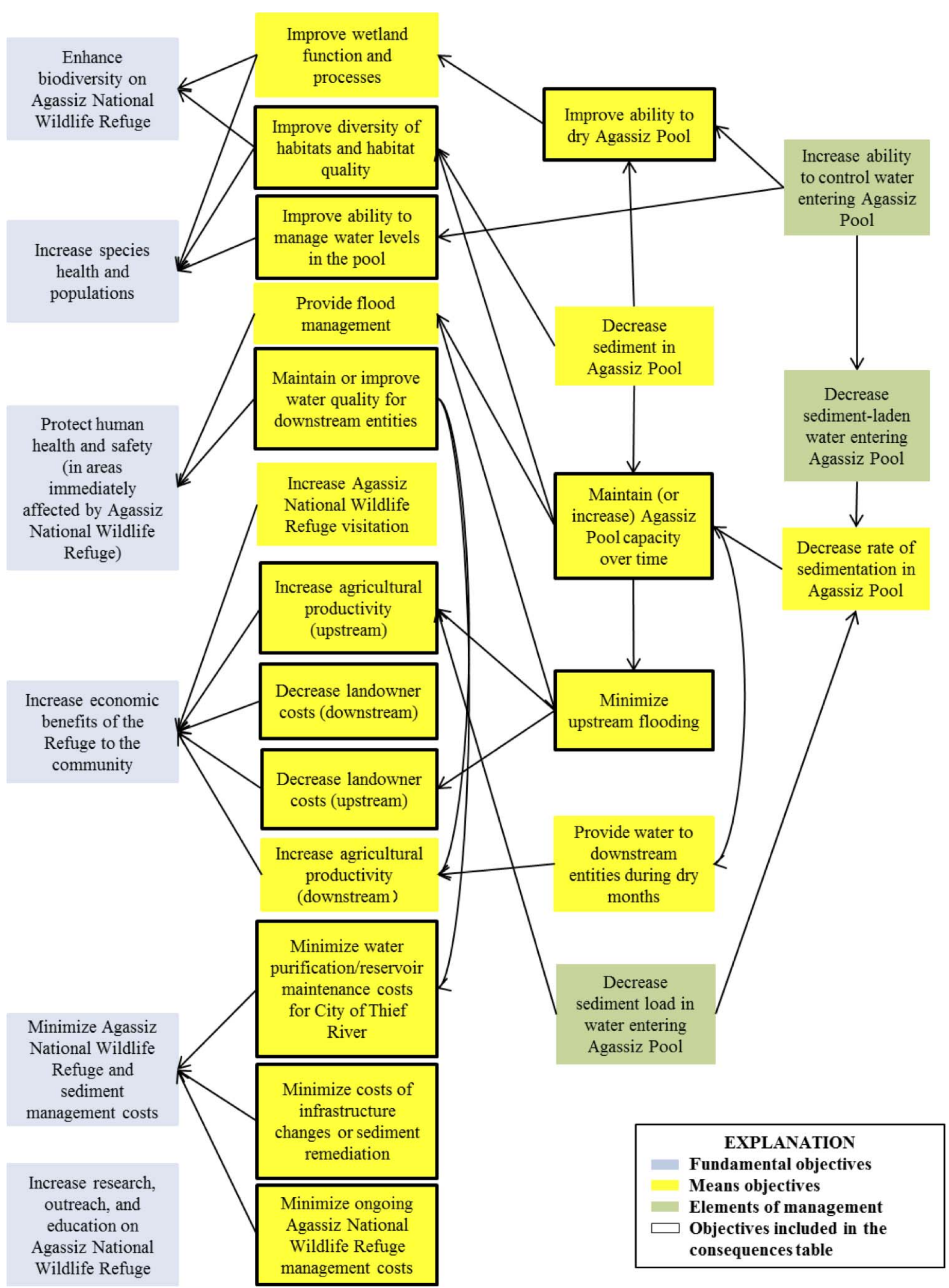

Figure 2. Means-ends diagram for sediment management at Agassiz National Wildlife Refuge, Minnesota, developed in consultation with Refuge staff in 2012. This diagram shows the relationship between broad types of management (green) and the fundamental objectives (blue) that staff wanted to achieve with their management. The means objectives are outcomes thought to be directly influenced by management (yellow) that would contribute to the fundamental objectives. Means objectives that were thought to be easily measured (outlined in black) were used to assess the alternative sediment management strategies. 
Table 1. Strategy generation table developed by the staff of Agassiz National Wildlife Refuge, Minnesota, and a stakeholder group at a structured decision making workshop in 2012 in Thief River Falls, Minnesota. This table is composed of action types aimed at managing sediment at Agassiz National Wildlife Refuge.

\begin{tabular}{llll}
\hline Action type & & \multicolumn{2}{c}{ Alternative actions } \\
\hline Reduce sediment upstream & Current programs & Increased program effort & Vegetation traps \\
Sediment traps & None & Physical traps & Bypass \\
Thief River bypass & No & Yes & Flow through (control structures) \\
Mud River diversion & No & Reconnect to Mud River & \\
Ditch 11 bypass & None & South bypass & Full cleanout and control structures \\
Restore Mud River & No & Yes & Dredging \\
Ditch 11 modifications & No change & Incremental mechanical removal & \\
Sediment removal from Agassiz Pool & None & Use drawdowns & \\
Cattail management & Current effort & Increased effort & \\
Management approaches to drawdowns & No change & Increase frequency and duration of drawdowns & \\
\hline
\end{tabular}

\section{Are There Other Cases Similar to Agassiz NWR in the Midwest and Great Plains?}

Following the process described above, we began to wonder whether other Refuges throughout the Midwest and Great Plains experienced negative consequences from increased sedimentation. A systematic study of sedimentation in the Refuge System is beyond the scope of this project. But we decided to survey staff throughout U.S. Fish and Wildlife Service Regions 3 (Midwest) and 6 (Mountain-Prairie) about whether they experienced negative effects from sedimentation. Region 3 covers an area that includes the states of Illinois, Indiana, lowa, Ohio, Michigan, Minnesota, Missouri, and Wisconsin; and Region 6 covers an area that includes the states of Colorado, Kansas, Montana, Nebraska, North Dakota, South Dakota, Utah, and Wyoming. We focused on these Regions because they contain landscapes that are similar to the one in our case study. We assumed that responses from this survey would provide an index of the number of cases similar to Agassiz NWR. Based on the number of cases, we can determine whether systematic study of this topic is justified.

We developed an online survey in which we asked a range of questions that allowed for multiple-choice and open-ended responses (Table S2; survey questions can also be found in the metadata for Post van der Burg et al. 2017). We developed these questions based on the information we gathered in our case study. We issued this survey to 56 Refuges across Regions 3 and 6 in the spring of 2014. We only focused on Refuges that contained wetlands with flow-through hydrology (e.g., an impoundment created on a stream or river). We selected these Refuges because they have the potential to be experiencing sedimentation effects similar to those at Agassiz NWR and because we wanted to limit the number of surveys we sent out to Refuges. The survey was not interactive, though we encouraged respondents to contact us if they had any questions.

We received 49 responses (raw response data can be found in Post van der Burg et al. 2017). We found that approximately $39 \%$ of the Refuges reported sedimentation as negatively affecting their ability to meet management objectives, while approximately $37 \%$ did not. However, about a quarter of the respondents did not know whether sedimentation negatively affected management ( $2 \%$ did not respond). We did not ask managers how confident they were in answering this question. But, approximately $75 \%$ of the respondents that reported negative impacts had identified water

Table 2. Alternative strategies for sediment remediation and mitigation developed by the staff of Agassiz National Wildlife Refuge, Minnesota, and a stakeholder group at a structured decision making workshop in 2012 in Thief River Falls, Minnesota. This table is composed of actions found in Table 1. These actions are organized in terms of the element of sediment management they affect.

\begin{tabular}{|c|c|c|c|}
\hline \multirow[b]{2}{*}{ Strategy } & \multicolumn{3}{|c|}{ Key elements of strategy } \\
\hline & $\begin{array}{l}\text { Reduce sediment } \\
\text { upstream }\end{array}$ & Control water inflow & Sediment removal \\
\hline 1. Upstream focus & Increased outreach & No changes & More drawdowns \\
\hline 2. Bypass focus & Existing outreach & $\begin{array}{l}\text { Thief River, Mud River, and Ditch } \\
11 \text { bypasses }\end{array}$ & More drawdowns \\
\hline 3. Emphasize drawdowns & Existing outreach & $\begin{array}{l}\text { Thief River bypass; reconnect Mud } \\
\text { River }\end{array}$ & $\begin{array}{l}\text { Incremental cleanup of Ditch } 11 ; \\
\text { Multiple drawdowns }\end{array}$ \\
\hline 4. Engineered strategy & Existing outreach & $\begin{array}{l}\text { Thief River bypass; reconnect Mud } \\
\text { River; Ditch } 11 \text { flow-through }\end{array}$ & $\begin{array}{l}\text { Clear Ditch 11, control structures; } \\
\text { Multiple drawdowns }\end{array}$ \\
\hline 5. Bypass and drawdown & Existing outreach & $\begin{array}{l}\text { Thief River, Mud River, and Ditch } \\
11 \text { bypasses }\end{array}$ & $\begin{array}{l}\text { Incremental cleanup of Ditch } 11 \text {; } \\
\text { Multiple-drawdowns }\end{array}$ \\
\hline 6. Engineer and drawdown & Existing outreach & $\begin{array}{l}\text { Thief River bypass; Ditch } 11 \text { flow- } \\
\text { through }\end{array}$ & $\begin{array}{l}\text { Incremental cleanup of Ditch } 11 ; \\
\text { Multiple drawdowns }\end{array}$ \\
\hline
\end{tabular}


Table 3. A preliminary assessment of alternative sediment management strategies developed by the staff of Agassiz National Wildlife Refuge, Minnesota, and a stakeholder group at a structured decision making workshop in 2012 in Thief River Falls, Minnesota. This table shows the performance of each strategy across a set of management objectives. Yellow cells represent the strategy that performed the best on a particular objective, whereas blue cells represent the worst performance.

\begin{tabular}{|c|c|c|c|c|c|c|c|c|c|c|}
\hline Strategies & & & & & Objec & tives & & & & \\
\hline & 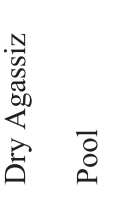 & 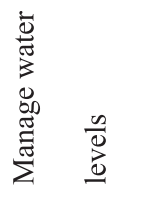 & 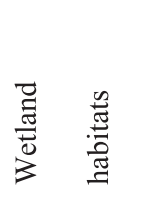 & 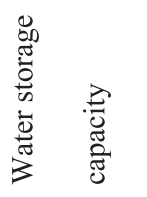 & 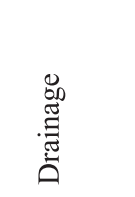 & 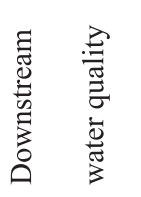 & 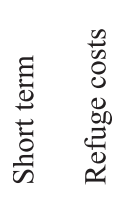 & $\begin{array}{l}0 \\
0 \\
0 \\
0 \\
0 \\
00 \\
\stackrel{0}{0} \\
\simeq\end{array}$ & 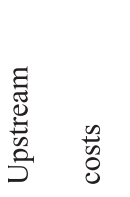 & 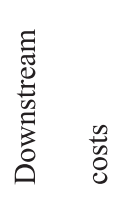 \\
\hline 1 & $\begin{array}{l}\text { Slight } \\
\text { increase }\end{array}$ & Decrease & Decrease & Decrease & Decrease & Decrease & $\begin{array}{l}\text { Slight } \\
\text { increase }\end{array}$ & Increase & $\begin{array}{l}\text { Slight } \\
\text { increase }\end{array}$ & $\begin{array}{l}\text { Slight } \\
\text { decrease }\end{array}$ \\
\hline 2 & Increase & Increase & Increase & $\begin{array}{l}\text { No } \\
\text { change }\end{array}$ & Increase & Decrease & $\begin{array}{l}\text { Large } \\
\text { increase }\end{array}$ & Increase & $\begin{array}{l}\text { No } \\
\text { change }\end{array}$ & Increase \\
\hline 3 & Increase & Increase & Increase & $\begin{array}{l}\text { No } \\
\text { change }\end{array}$ & Increase & Decrease & Increase & $\begin{array}{l}\text { Slight } \\
\text { increase }\end{array}$ & $\begin{array}{l}\text { Slight } \\
\text { increase }\end{array}$ & Increase \\
\hline 4 & $\begin{array}{l}\text { Large } \\
\text { increase }\end{array}$ & Increase & Increase & Increase & Increase & Decrease & $\begin{array}{l}\text { Large } \\
\text { increase }\end{array}$ & $\begin{array}{l}\text { Large } \\
\text { increase }\end{array}$ & $\begin{array}{l}\text { No } \\
\text { change }\end{array}$ & Increase \\
\hline 5 & $\begin{array}{l}\text { Large } \\
\text { increase }\end{array}$ & $\begin{array}{l}\text { Large } \\
\text { increase }\end{array}$ & Increase & Increase & $\begin{array}{l}\text { Large } \\
\text { increase }\end{array}$ & Increase & $\begin{array}{l}\text { Large } \\
\text { increase }\end{array}$ & Increase & $\begin{array}{l}\text { Slight } \\
\text { increase }\end{array}$ & $\begin{array}{l}\text { Slight } \\
\text { increase }\end{array}$ \\
\hline 6 & $\begin{array}{l}\text { Large } \\
\text { increase }\end{array}$ & Increase & Increase & $\begin{array}{l}\text { Large } \\
\text { increase }\end{array}$ & Increase & $\begin{array}{l}\text { Slight } \\
\text { increase }\end{array}$ & Increase & Increase & $\begin{array}{l}\text { Slight } \\
\text { increase }\end{array}$ & $\begin{array}{l}\text { Slight } \\
\text { increase }\end{array}$ \\
\hline
\end{tabular}

quality impairments (Figure S1). Only approximately 55\% of those that reported no negative impacts identified such impairments. We asked respondents open-ended questions asking for more detail about these impairments or whether they wanted to share additional information. Approximately $82 \%$ of those who responded provided additional details about the nature of sedimentation or other more important problems on their Refuges. Those who identified impairments were much more likely to provide additional details describing sedimentation on their Refuges (94\% of those reporting negative impacts provided additional details, $100 \%$ of those reporting no impacts provided additional details). Those staff who did not identify impairments were less likely to provide additional details $(40 \%$ of those reporting negative impacts, $67 \%$ of those reporting no impacts). We contend that providing those additional details indicated that some Refuge staff had information or experience to determine whether sedimentation affected management. However, we recognize that there still may be some staff that answered questions but do not have specific knowledge or experience to assess the impacts of sedimentation.

We then compared responses to other questions between Refuges that identified sedimentation impacts and those that did not. The responses suggest that the characteristics of Refuges among the two groups are similar (Figures S2-S7). We found a slightly larger proportion of Refuges reporting negative effects in lower watershed positions (i.e., lower basin) compared with Refuges reporting no negative effects (Figure 3 ). We also found more diverse upstream land-use types around Refuges reporting no negative impacts. More Refuges reporting negative effects were associated with agricultural and urban land use (Figure 4) and landscapes with highly erodible soils (Figure S8).

We then looked only at Refuges reporting negative sedimentation effects. The single largest effect was to 


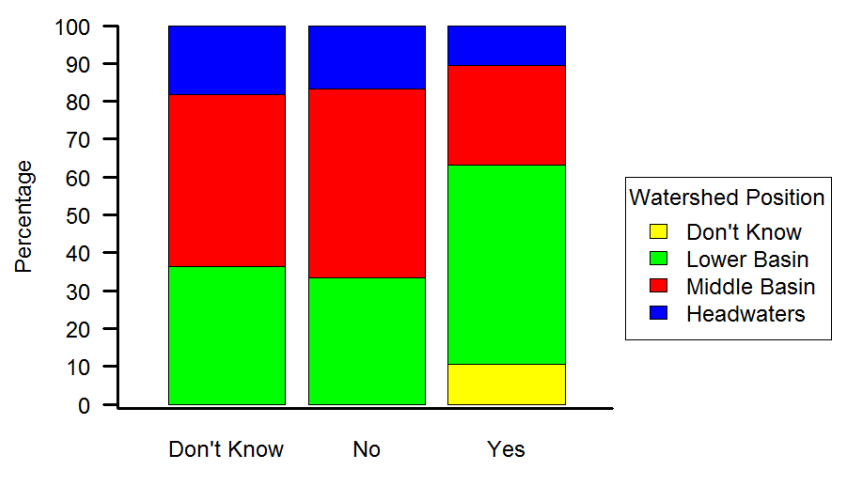

Does sedimentation affect refuge management objectives?

Figure 3. Responses from 49 National Wildlife Refuges in U.S. Fish and Wildlife Service Region 3 (an area encompassing the states of Illinois, Indiana, lowa, Ohio, Michigan, Minnesota, Missouri, and Wisconsin) and Region 6 (an area encompassing the states of Colorado, Kansas, Montana, Nebraska, North Dakota, South Dakota, Utah, and Wyoming) to the following question: In general, how would you describe the watershed position of Refuge streams, rivers, or ditches that deliver water to Refuge wetlands and impoundments? Respondents could choose from one of four answers. The responses were summarized as the percentage of respondents that chose an answer to the question above and also answered the question: Has your ability to effectively meet the management objectives for your Refuge been substantially reduced by sedimentation? These questions were part of an online survey about sedimentation in the National Refuge System issued during the months of March and April, 2014.

water quality; followed by changes in plant community composition; the distribution of other species, including invasive species; and management-related problems, including controlling water levels and maintenance of Refuge infrastructure (Figure 5). Respondents also reported that sediment entered their Refuges from external sources, with an almost even split between sediment entering continuously from upstream sources and entering during large flood events (Figure S9).

\section{How Should the National Wildlife Refuge System Proceed with Assessing the Extent of Sedimentation-related Problems?}

\section{Conduct a formal assessment and put sedimentation in context with other management needs}

The results of our survey make the point that cases like Agassiz NWR are not isolated. This suggests a comprehensive look at the problem of sedimentation among Refuges is warranted. But before we discuss what our survey suggests, we should point out the inferential limitation of our survey. First, we did not randomly select Refuges throughout the entire system, but instead focused on Refuges that were similar to Agassiz NWR in two Regions. Secondly, our questions focused on sedimentation rather than Refuge management generally. As a result, we cannot draw conclusions about the relative importance of sedimentation across Refuges.

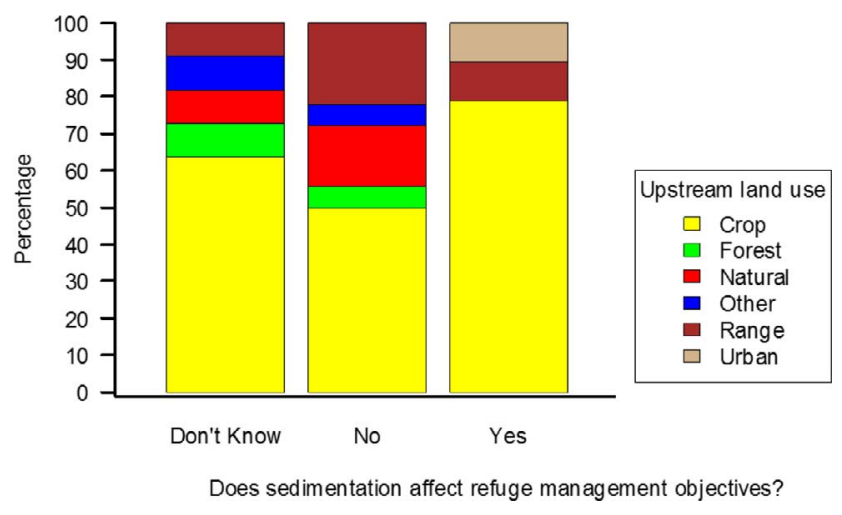

Figure 4. Responses from 49 National Wildlife Refuges in U.S. Fish and Wildlife Service Region 3 (an area encompassing the states of Illinois, Indiana, lowa, Ohio, Michigan, Minnesota, Missouri, and Wisconsin) and Region 6 (an area encompassing the states of Colorado, Kansas, Montana, Nebraska, North Dakota, South Dakota, Utah, and Wyoming) to the following question: What is the predominant land use type upstream of your Refuge? Respondents could choose from one of four options, or could specify their own answer. The responses were summarized as the percentage of respondents that chose an answer to the question above and also answered the question: Has your ability to effectively meet the management objectives for your Refuge been substantially reduced by sedimentation? These questions were part of an online survey about sedimentation in the National Refuge System issued during the months of March and April, 2014.

Despite these limitations, our results show that a portion of Refuge staff think sedimentation is interfering with their management. We think this finding justifies the need to develop a more holistic survey of Refuges. Such a survey would need to include a rigorous sampling design, a broad cross-section of Refuges across the country, and detailed questions about a range of stressors, in addition to sedimentation. Such an assessment provides necessary information about whether monitoring and managing sedimentation across the Refuge System is worth the investment. This is important to know because several of the Refuges that reported no negative sedimentation-related effects did still identify other water-quality impairments (e.g., contaminants) as pressing problems. Still others pointed out that decreased funding and lack of personnel restricted management. In the example of Agassiz NWR, sedimentation appeared to be the underlying cause of a number of other problems (e.g., persistent cattail), but budget limitations created a trade-off in terms of the preferred solution. In a broader sense, understanding the larger management context for individual Refuges is critical in identifying which stressors are driving any perceived failure to reach management objectives.

\section{Determine where sedimentation is likely to be a problem using a quantitative approach}

It is apparent from our survey that some Refuge staff did not know whether sedimentation affected their 


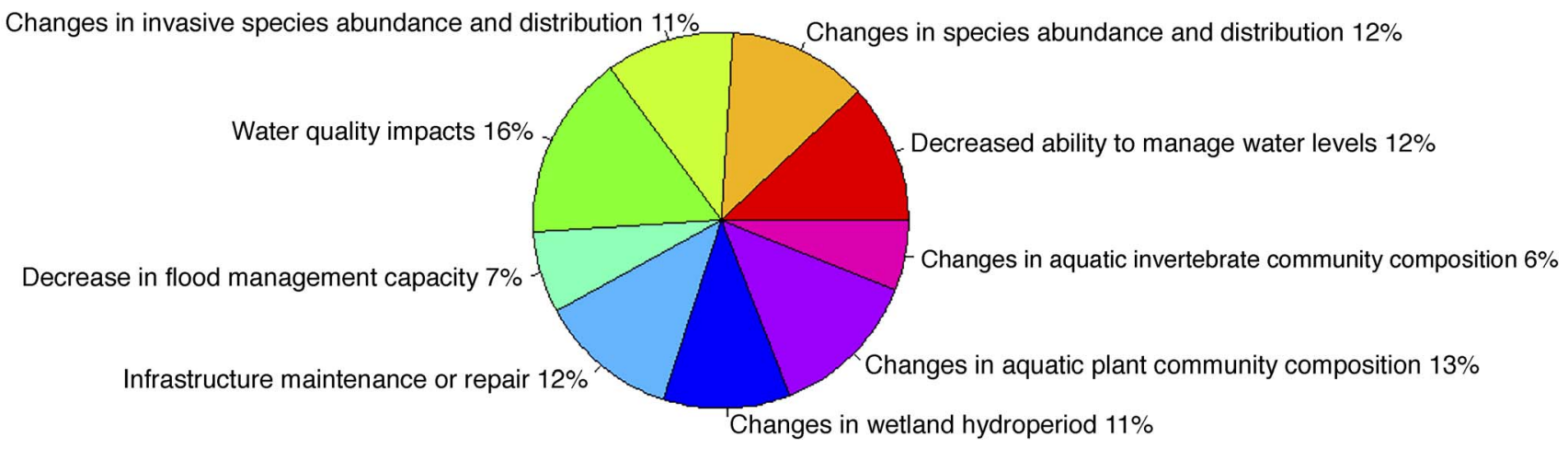

Figure 5. Responses from 19 National Wildlife Refuges in U.S. Fish and Wildlife Service Region 3 (an area encompassing the states of Illinois, Indiana, lowa, Ohio, Michigan, Minnesota, Missouri, and Wisconsin) and Region 6 (an area encompassing the states of Colorado, Kansas, Montana, Nebraska, North Dakota, South Dakota, Utah, and Wyoming) to the following question: What have been the impacts of sedimentation? These 19 Refuges also answered "Yes" to the question: Has your ability to effectively meet the management objectives for your Refuge been substantially reduced by sedimentation? Respondents could choose from any number of 9 options, or could specify their own answer. Only the 9 options are shown. These questions were part of an online survey about sedimentation in the National Refuge System issued during the months of March and April, 2014.

management. Thus, they may not know how to put sedimentation into context with other management problems. Managers may also not know whether undesirable conditions on their Refuges are ultimately linked to sedimentation. Informing staff about whether this is the case requires the allocation of funding to study sedimentation across the Refuge System. We suggest that some form of predictive modeling be used for targeting Refuges that are at risk of being affected by sedimentation. A quantitative approach would likely use factors such as watershed position and land use to make predictions about where increased sedimentation is most likely. Such an approach should also include wetlands that are not flow-through impoundments as well. One should also keep in mind that while we discuss sedimentation risk in terms of the physical effects of sedimentation (e.g., filling up wetland basins), there may be other more subtle effects from stressors like contaminants from agricultural runoff. Thus, further predictive refinements should distinguish between the types of likely impacts from land use more generally.

\section{Develop an understanding of the interplay between management and sedimentation, and develop Refuge-specific strategies}

From our survey it appears that Refuge operations may not have a large influence on increasing the negative effects of sedimentation. However, this likely reflects the Refuges we surveyed, which we screened to only include those with similar characteristics. Unfortunately, we did not query Refuge staff about the degree to which they believed ongoing management strategies and protocols contributed to increased sedimentation. This is an important question to answer because management strategies that result in longer term water retention, or infrequent drawdowns, could trap greater quantities of the sediment entering wetlands. Other aspects of an impoundment, such as its age or design, are also likely to influence sedimentation rates. We suggest that developing a better understanding of the interplay between the physical location of a Refuge, water management techniques, and sediment sources is one of the first steps toward developing better management plans on Refuges where sedimentation impacts management performance. This is important because management is the easiest aspect of this problem to control, but may have a relatively small effect on sedimentation. Factors such as watershed area or land use are much more difficult to control, but may have a stronger influence on sedimentation rates. Thus, the effectiveness of mitigation strategies on Refuges will vary depending on the surrounding landscape, as well as their management histories. Those who develop mitigation plans will need to account for these idiosyncrasies, as well as the management objectives of other interested groups. The process outlined in our case study provides a template for a process that may be useful for Refuges interested in developing transparent solutions to sedimentation-related problems.

\section{Create a portfolio approach for investing in stressors across the National Wildlife Refuge System}

The case study we presented in this paper focused on using decision analysis to deal with problems specific to individual Refuges related to increased sedimentation. We contend that the suggestions we make above are consistent with the steps necessary to perform a decision analysis of management decisions more generally. For example, the process of conducting a thorough survey of stressors throughout the Refuge System is analogous to the decision framing step of the decision analysis process. One could also envision predicting Refuges at risk as leading toward an assessment of investment outcomes. All of this could lead to a larger portfolio analysis that the Refuge System could use to decide how to invest scarce resources in managing threats and 
stressors. A survey like the one we propose here could be coupled with workshops and discussions with individual Refuges to develop Refuge System objectives. These objectives could then be used to optimize investments in mitigating and remediated the effects of stressors, including increased sedimentation. In the context of portfolio analysis, one could use the objectives and quantitative modeling to assess how investments in various strategies at the Refuge-level collectively help staff manage their Refuges. Depending on the results of such an analysis, monitoring and remediation plans could then be developed and tailored to each Refuge. Periodic assessments of Refuges could also be looked at in terms of how they contribute to system-wide objectives. While such an approach would be useful in putting the management of increased sedimentation in context with other stressors, it may also illuminate larger management problems at the level of the Refuge System.

\section{Supplemental Material}

Please note: The Journal of Fish and Wildlife Management is not responsible for the content or functionality of any supplemental material. Queries should be directed to the corresponding author for the article.

Table S1. Detailed qualitative assessment of the performance of sediment management strategies across management objectives. The objectives, the alternative strategies, and the assessment were developed by staff at Agassiz National Wildlife Refuge, Minnesota, in 2012.

Found at DOI: http://dx.doi.org/10.3996/012016JFWM-004.S1 (18 KB DOCX).

Table S2. List of questions and allowed responses for an online sedimentation survey given to National Wildlife Refuge (Minnesota) staff in U.S. Fish and Wildlife Service Region 3 (an area encompassing the states of Illinois, Indiana, lowa, Ohio, Michigan, Minnesota, Missouri, and Wisconsin) and Region 6 (an area encompassing the states of Colorado, Kansas, Montana, Nebraska, North Dakota, South Dakota, Utah, and Wyoming) in the spring of 2014.

Found at DOI: http://dx.doi.org/10.3996/012016JFWM-004.S2 (15 KB DOCX).

Figure S1. Responses from 49 National Wildlife Refuges in U.S. Fish and Wildlife Service Region 3 (an area encompassing the states of Illinois, Indiana, lowa, Ohio, Michigan, Minnesota, Missouri, and Wisconsin) and Region 6 (an area encompassing the states of Colorado, Kansas, Montana, Nebraska, North Dakota, South Dakota, Utah, and Wyoming) to the following question: Have any water quality issues (e.g., elevated salinity, nutrients, mercury) been formally identified on your Refuge? Respondents could choose from one of three options. The responses were summarized as the percentage of respondents that chose an answer to the question above and also answered the question: Has your ability to effectively meet the management objectives for your Refuge been substantially reduced by sedimentation? These questions were part of an online survey about sedimentation in the National Refuge System issued during the months of March and April, 2014.

Found at DOI: http://dx.doi.org/10.3996/012016JFWM-004.S3 (15 KB DOCX).

Figure S2. Responses from 49 National Wildlife Refuges in U.S. Fish and Wildlife Service Region 3 (an area encompassing the states of Illinois, Indiana, lowa, Ohio, Michigan, Minnesota, Missouri, and Wisconsin) and Region 6 (an area encompassing the states of Colorado, Kansas, Montana, Nebraska, North Dakota, South Dakota, Utah, and Wyoming) to the following question: Have there been any hydrologic alterations (e.g., construction of impoundments) on your Refuge? Respondents could select one of three answers. The responses were summarized as the percentage of respondents that chose an answer. This question was part of an online survey about sedimentation in the National Refuge System issued during the months of March and April, 2014.

Found at DOI: http://dx.doi.org/10.3996/012016JFWM-004.S4 (15 KB DOCX).

Figure S3. Responses from 49 National Wildlife Refuges in U.S. Fish and Wildlife Service Region 3 (an area encompassing the states of Illinois, Indiana, lowa, Ohio, Michigan, Minnesota, Missouri, and Wisconsin) and Region 6 (an area encompassing the states of Colorado, Kansas, Montana, Nebraska, North Dakota, South Dakota, Utah, and Wyoming) to the following question: What types of hydrologic alterations have been made on your Refuge? Respondents could choose from one of five options, or could specify their own answer. The responses were summarized as the percentage of respondents that chose an answer to the question above and also answered the question: Has your ability to effectively meet the management objectives for your Refuge been substantially reduced by sedimentation? These questions were part of an online survey about sedimentation in the National Refuge System issued during the months of March and April, 2014.

Found at DOI: http://dx.doi.org/10.3996/012016JFWM-004.S5 (15 KB DOCX).

Figure S4. Responses from 49 National Wildlife Refuges in U.S. Fish and Wildlife Service Region 3 (an area encompassing the states of Illinois, Indiana, lowa, Ohio, Michigan, Minnesota, Missouri, and Wisconsin) and Region 6 (an area encompassing the states of Colorado, Kansas, Montana, Nebraska, North Dakota, South Dakota, Utah, and Wyoming) to the following question: Have there been any hydrologic alterations (e.g., ditch or impoundment creation) upstream of your Refuge? Respondents could choose from one of three options, or could specify their own answer. The responses were summarized as the percentage of respondents that chose an answer to the question above and also 
answered the question: Has your ability to effectively meet the management objectives for your Refuge been substantially reduced by sedimentation? These questions were part of an online survey about sedimentation in the National Refuge System issued during the months of March and April, 2014.

Found at DOI: http://dx.doi.org/10.3996/012016JFWM-004.S6 (15 KB DOCX).

Figure S5. Responses from 49 National Wildlife Refuges in U.S. Fish and Wildlife Service Region 3 (an area encompassing the states of Illinois, Indiana, lowa, Ohio, Michigan, Minnesota, Missouri, and Wisconsin) and Region 6 (an area encompassing the states of Colorado, Kansas, Montana, Nebraska, North Dakota, South Dakota, Utah, and Wyoming) to the following question: What types of hydrologic alterations have been upstream of your Refuge? Respondents could choose from one of five options, or could specify their own answer. The responses were summarized as the percentage of respondents that chose an answer to the question above and also answered the question: Has your ability to effectively meet the management objectives for your Refuge been substantially reduced by sedimentation? These questions were part of an online survey about sedimentation in the National Refuge System issued during the months of March and April, 2014.

Found at DOI: http://dx.doi.org/10.3996/012016JFWM-004.S7 (15 KB DOCX).

Figure S6. Responses from 49 National Wildlife Refuges in U.S. Fish and Wildlife Service Region 3 (an area encompassing the states of Illinois, Indiana, lowa, Ohio, Michigan, Minnesota, Missouri, and Wisconsin) and Region 6 (an area encompassing the states of Colorado, Kansas, Montana, Nebraska, North Dakota, South Dakota, Utah, and Wyoming) to the following question: How would you classify wetlands on your Refuge? Respondents could choose from one of six options, or could specify their own answer. The responses were summarized as the percentage of respondents that chose an answer to the question above and also answered the question: Has your ability to effectively meet the management objectives for your Refuge been substantially reduced by sedimentation? These questions were part of an online survey about sedimentation in the National Refuge System issued during the months of March and April, 2014.

Found at DOI: http://dx.doi.org/10.3996/012016JFWM-004.S8 (15 KB DOCX).

Figure S7. Responses from 49 National Wildlife Refuges in U.S. Fish and Wildlife Service Region 3 (an area encompassing the states of Illinois, Indiana, lowa, Ohio, Michigan, Minnesota, Missouri, and Wisconsin) and Region 6 (an area encompassing the states of Colorado, Kansas, Montana, Nebraska, North Dakota, South Dakota, Utah, and Wyoming) to the following question: What is the primary water source for wetlands on your Refuge? Respondents could choose from one of four options. The responses were summarized as the percentage of respondents that chose an answer to the question above and also answered the question: Has your ability to effectively meet the management objectives for your Refuge been substantially reduced by sedimentation? These questions were part of an online survey about sedimentation in the National Refuge System issued during the months of March and April, 2014.

Found at DOI: http://dx.doi.org/10.3996/012016JFWM-004.S9 (15 KB DOCX).

Figure S8. Responses from 49 National Wildlife Refuges in U.S. Fish and Wildlife Service Region 3 (an area encompassing the states of Illinois, Indiana, lowa, Ohio, Michigan, Minnesota, Missouri, and Wisconsin) and Region 6 (an area encompassing the states of Colorado, Kansas, Montana, Nebraska, North Dakota, South Dakota, Utah, and Wyoming) to the following question: In general, how would you describe the erodibility of soils upstream of your Refuge? Respondents could choose from one of three options. The responses were summarized as the percentage of respondents that chose an answer to the question above and also answered the question: Has your ability to effectively meet the management objectives for your Refuge been substantially reduced by sedimentation? These questions were part of an online survey about sedimentation in the National Refuge System issued during the months of March and April, 2014.

Found at DOI: http://dx.doi.org/10.3996/012016JFWM-004.S10 (21 KB DOCX).

Figure S9. Responses from 19 National Wildlife Refuges in U.S. Fish and Wildlife Service Region 3 (an area encompassing the states of Illinois, Indiana, lowa, Ohio, Michigan, Minnesota, Missouri, and Wisconsin) and Region 6 (an area encompassing the states of Colorado, Kansas, Montana, Nebraska, North Dakota, South Dakota, Utah, and Wyoming) to the following question: What is the primary transport mechanism for the majority of sediment loading to wetlands on your Refuge? These 19 Refuges also answered "Yes" to the question: Has your ability to effectively meet the management objectives for your Refuge been substantially reduced by sedimentation? Respondents could choose from one of three options, or could specify their own answer. The responses were summarized as the percentage of respondents that chose a particular answer. These questions were part of an online survey about sedimentation in the National Refuge System issued during the months of March and April, 2014.

Found at DOI: http://dx.doi.org/10.3996/012016JFWM-004.S11 (15 KB DOCX).

Reference S1. Fitzpatrick FA, Knox JC, SchubauerBerigan JP. 2007. Sedimentation history of Halfway Creek Marsh, Upper Mississippi Wildlife and Fish Refuge, Wisconsin, 1846-2006. U.S. Geological Survey Scientific Investigations Report 2007-5209.

Found at DOI: http://dx.doi.org/10.3996/012016JFWM-004.S12 (3907 KB PDF); also available at http:// pubs.er.usgs.gov/publication/sir20075209 (3.81 MB PDF). 
Reference S2. Hanson, C. 2010. Thief River sediment investigation final report: Thief River Falls, Minn., Red Lake Watershed District, 228 p. Found at DOI: https://doi. org/10.3996/012016-JFWM-004.S13 (32,208 KB PDF); also available at http://www.redlakewatershed.org/ waterquality/Thief\%20River\%20Watershed\%20Sediment $\%$ 20Investigation\%20Final\%20Report.pdf (32,208 KB PDF).

Reference S3. Heimann DC, Richards JM. 2003. Topography and sedimentation characteristics of the Squaw Creek National Wildlife Refuge, Holt County, Missouri, 1937-2002. U.S. Geological Survey WaterResources Investigations Report 03-4211.

Found at DOI: https://doi.org/10.3996/012016-JFWM004.S14 (5137 KB PDF); ; also available at http://pubs.er. usgs.gov/publication/wri034211 (5137 KB PDF).

Reference S4. Houston Engineering, Inc. 2010. Thief River SWAT modeling Thief River Watershed, Minnesota-Numerical modeling and evaluation of management scenarios. Maple Grove, Minn., Houston Engineering, Inc., 76 p. Found at DOI: https://doi.org/10.3996/012016JFWM-004.S15 (10,200 KB PDF); also available: http:// www.redlakewatershed.org/waterquality/TRW_Report. pdf $(10,200 \mathrm{~KB}$ PDF).

Reference S5. Nustad RA, Galloway JM. 2012. Assessment of nutrients and suspended sediment conditions in and near the Agassiz National Wildlife Refuge, Northwest Minnesota, 2008-2010. U.S. Geological Survey Scientific Investigations Report 2012-5112. Found at DOI: https://doi.org/10.3996/012016-JFWM004.S16 (3,513 KB PDF);

also available at http://pubs.usgs.gov/sir/2012/5112/ (3.42 MB PDF).

Reference S6. Schottler SP, Engstrom DR. 2011. Sediment loading and sources to Agassiz National Wildlife Refuge. St. Croix Watershed Research Station Final Report.

Found at DOI: https://doi.org/10.3996/012016-JFWM$004 . S 17$ (11,318 KB PDF); also available at https://catalog. data.gov/dataset/sediment-loading-and-sources-toagassiz-national-wildlife-refuge (11.1 MB PDF).

Reference S7. Tangen BA, Laubhan MK, Gleason RA. 2014. Assessment of sediments in the riverine impoundments of national wildlife refuges in the Souris River Basin, North Dakota: U.S. Geological Survey Scientific Investigations Report 2014-5018. Found at DOI: https:// doi.org/10.3996/012016-JFWM-004.S18 (32,933 KB PDF);

also available at https://pubs.er.usgs.gov/publication/ sir20145018 (32.1 MB PDF).

\section{Acknowledgments}

We would like to thank the staff of U.S. Fish and Wildlife Service National Wildlife Refuges in Region 3 (an area encompassing the states of Illinois, Indiana, lowa, Ohio, Michigan, Minnesota, Missouri, and Wisconsin) and Region 6 (an area encompassing the states of Colorado, Kansas, Montana, Nebraska, North Dakota, South Dakota,
Utah, and Wyoming) for their time in answering our survey questions. We would also like to thank National Wildlife Refuge System leadership in these regions for viewing this survey as a priority exercise for their staff. Likewise, we would like to thank Cami Dixon, Jeff Warren, and Murray Laubhan for their coordination efforts and site selection input in surveying Region 6 refuges. Finally, we would like to thank the three anonymous reviewers and Associate Editor who provided constructive comments on earlier versions of this manuscript.

Any use of trade, product, website, or firm names in this publication is for descriptive purposes only and does not imply endorsement by the U.S. Government.

\section{References}

Barendregt AA, Swarth CW. 2013. Tidal freshwater wetlands-variation and changes. Estuaries and Coasts 36:445-456.

Beas BJ, Smith LM, LaGrange TG, Stutheit R. 2013. Effects of sediment removal on vegetation communities in Rainwater Basin playa wetlands. Journal of Environmental Management 128:371-379.

Burris L, Skagen SK. 2013. Modeling sediment accumulation in North American playa wetlands in response to climate change, 1940-2100. Climatic Change 117:69-83.

Clemen RT, Reilly T. 2001. Making hard decisions. Pacific Grove, California: Duxbury.

Fitzpatrick FA, Knox JC, Schubauer-Berigan JP. 2007. Sedimentation history of Halfway Creek Marsh, Upper Mississippi Wildlife and Fish Refuge, Wisconsin, 18462006. U.S. Geological Survey Scientific Investigations Report 2007-5209 (see Supplemental Material, Reference S1, https://doi.org/10.3996/012016-JFWM-004. S12); also available: http://pubs.er.usgs.gov/ publication/sir20075209 (April 2017).

Gleason RA, Euliss NH, Hubbard DE, Duffy WG. 2003. Effects of sediment load on emergence of aquatic invertebrates and plants from wetland soil egg and seed banks. Wetlands 23:26-34.

Gregory R, Failing L, Harstone M, Long G, McDaniels T, Ohlson D. 2012. Structured decision making: a practical guide to environmental management choices. West Sussex, England, UK: Wiley-Blackwell.

Hanson, C. 2010. Thief River sediment investigation final report. Thief River Falls, Minn., Red Lake Watershed District, 228 p. (see Supplemental Material, Reference S2, https://doi.org/10.3996/012016-JFWM-004.S13); also available: http://www.redlakewatershed.org/ waterquality/Thief $\% 20$ River $\% 20$ Watershed $\%$ 20Sediment\%20Investigation\%20Final\%20Report.pdf (April 2017).

Heimann DC, Richards JM. 2003. Topography and sedimentation characteristics of the Squaw Creek National Wildlife Refuge, Holt County, Missouri, 1937-2002. U.S. Geological Survey Water-Resources Investigations Report 03-4211 (see Supplemental 
Material, Reference S3, https://doi.org/10.3996/ 012016-JFWM-004.S14); also available: http://pubs.er. usgs.gov/publication/wri034211 (April 2017).

Houston Engineering, Inc. 2010. Thief River SWAT modeling Thief River Watershed, Minnesota-Numerical modeling and evaluation of management scenarios. Maple Grove, Minn., Houston Engineering, Inc., 76 p. (see Supplemental Material, Reference S4, https:// doi.org/10.3996/012016-JFWM-004.S15); also available: http://www.redlakewatershed.org/waterquality/ TRW_Report.pdf (April 2017).

Keeney RL. 1992. Value-focused thinking. Cambridge, Massachusetts: Harvard University Press.

Keeney RL. 2004. Making better decision makers. Decision Analysis 1:193-204.

Kreiling RM, Schubauer-Berigan JP, Richardson WB, Bartsch LA, Hughes PE, Cavanaugh JC, Strauss EA. 2013. Wetland management reduces sediment and nutrient loading to the upper Mississippi River. Journal of Environmental Quality 42:573-583.

Nustad RA, Galloway JM. 2012. Assessment of nutrients and suspended sediment conditions in and near the Agassiz National Wildlife Refuge, Northwest Minnesota, 2008-2010. U.S. Geological Survey Scientific Investigations Report 2012-5112 (see Supplemental Material, Reference S5, https://doi.org/10.3996/ 012016-JFWM-004.S16); also available: http://pubs. usgs.gov/sir/2012/5112/ (April 2017).
Post van der Burg M, Eash JD, Knutsen GA. 2017. Data file containing the raw responses to an online sedimentation survey from 49 National Wildlife Refuges in U.S. Fish and Wildlife Service Region 3 and Region 6. U.S. Geological Survey data release. Available: https://doi. org/10.5066/F7C24TKS (April 2017).

Schottler SP, Engstrom DR. 2011. Sediment loading and sources to Agassiz National Wildlife Refuge. St. Croix Watershed Research Station Final Report (see Supplemental Material, Reference S6, https://doi.org/10.3996/ 012016-JFWM-004.S17); also available: https://catalog. data.gov/dataset/sediment-loading-and-sources-toagassiz-national-wildlife-refuge (April 2017).

Tangen BA, Laubhan MK, Gleason RA. 2014. Assessment of sediments in the riverine impoundments of national wildlife refuges in the Souris River Basin, North Dakota: U.S. Geological Survey Scientific Investigations Report 2014-5018 (see Supplemental Material, Reference S7, https://doi.org/10.3996/012016-JFWM-004.S18); also available: https://pubs.er.usgs.gov/publication/ sir20145018 (April 2017).

Tsai JS, Venne LS, McMurry ST, Smith LM. 2012. Local and landscape influences on plant communities in playa wetlands. Journal of Applied Ecology 49:174-181.

Venne, LS, Tsai JS, Cox SB, Smith LM, McMurry ST. 2012. Amphibian community richness in cropland and grassland playas in the Southern High Plains, USA. Wetlands 32:619-629. 